\title{
Preparation and Evaluation of PolyVinyl Alcohol Derivative as Antimicrobial and Antifungal Agents.
}

Ali.N.Abed*

\author{
Jawad .K.Al-Kafaji ** \\ M.A.El-Azmirly**
}

Ithar.K.Al-Mayaly****

Date of acceptance 10/10/2007

\begin{abstract}
:
Polyvinal alcohol was Cynoethylated, complex compound with Iodin in presence of $\mathrm{Cu}^{++}$ions were preparated and their ultra violet (U.V) and infra red( IR) spectra were investigated.

The prepared derivative and complexes were evaluated as antibacterial and antifungal agents following the standard dilution method. MIC(minimum inhibitory concentration) for each polymer using ten types of gram ${ }^{+}$ve and gram - ve bacteria were determinated in addition to three types of fungi. The results obtainded showed that MIC's were around 0.0011 $\times 10^{3}$ molar for different polymetric derivatives tried.
\end{abstract}

\section{Introduction:}

Now days polymeric substances have attained invaluable important in medicine as well as in nearly every sphere of life. Their relatively easy variability of physical and chemical propreties enables accommodation to many different requirement.

Only during the last two decades it has been recognized that the interaction of synthesis polymers with biological materials can also be flavorable and desirable .Thus, polyglycolide and polylactide, which are applied as sutures materials in surgery, are slowly degraded and resorbed in the body.

Definite pharmacological properties have been discovered in the case of other polymers. Polymers can thus, provide a safe ( not inherently toxic) universal platform for administering biological compounds which need amore controlled delivery (1).

Ikada et al. (1984) synthesized polymers of quaternary ammonium salt surfactants and observed their antibacterial activity (2).
Senuma et al.(1989)have investigated copolymerization of acrylonitrile and substituted styrenes which are derived from chloromethyle styrenes tertiary amines and have examined the antibacterial activity of the copolymers.

It was also found that where antibacterial agent like penicillin is linked to poly(Vinyl amine), its about 30-40 times longer lasting than that of free pencillin (4).

In this connection, we have prepared some derivatives of the water soluble poly (Vinyl alcohol) and examined the antibacterial and antifungal activites of the prepared entities.

Poly vinyl alcohol (PVA) ,a polyhydroxy polymer, is the largest volume, synthetic, water -soluble resin produced in the world .It is commercially produced by the hydrolysis of poly vinyl caetate, as the vinyl alcohol monomer does not exist in the free state, although traces have been detected (5).It is with

*Department of Science ,College of Basic Education, Al-Mustansryia university.

** Department of Chemistry, College of Education, University of Baghdad.

*** Department of Biology, College of Science, University of Baghdad. 
melocular weight about 14.000 , So the hydrolysis and molecular weight have effect on the properties of Poly vinyl alcohol leds to varations inthis properties depends on the increasing or decreasing of molecular weight at a constant degree of hydrolysis and increasing of or decreacing of hydrolysis at a a constant molecular weight(6).

\section{Material And Methods: \\ 1-Materials :}

All chemical used were obtained from BDH Chemical Ltd U.K.,and they are analytical grade.

Biomaterials were obtained from oxide or Biomerieux Ltd.

\section{2-Methods:}

\subsection{Cynoethylation of poly vinyl alcohol.}

A slurry of 0.00032 mole polyvinyl alcohol (PVA) and 0.5 mole acrylonitrile (AN) and $0.5 \%$ aqueous of sodium hydroxide was refused under continuos stirring for 45 min.the reaction mixture was then cooled and neutralized with glacial acetic acid.

The product was poured in to about $0.2 \mathrm{~L}$ diethyl ether a taffy like precipitate was obtained, the precipitate was further purified by dissolving in $300 \mathrm{ml}$ of acetone and again precipited by pouring into diethyl ether. The product was then dried in vacum oven until constant weightin order to let the yield was almost quantitative.

The polymer was characterized by elemental analysis, ifrared and ultrviolet spectra

\subsection{Preparation of -A-Iodine complex:}

The method used was a modified one based on method of Toshihiro et al.(1986) : 0.5 gm PVA was dissolved in 5 $\mathrm{ml}$ distilled water $0.4 \mathrm{gm}$ sublimed Iodine one 0.16 gm $\mathrm{NaOH}$ was added and the mixture was heated at 25-30 $\mathrm{C}^{\circ}$ under continous stirring for two hours., the reaction mixture was cooled kept in refrigerator over night and kept in brown bottle and used for antimicrobial and antifungal test the material was charactrizied by ultraviolet and infrared spectra.

\subsection{Preparation of complex compound between PVC,Copper II and I $_{2}$ \\ The method followed was to add} copper (II)nitrate and Sodium hydroxide to a solution of 0.5 PVA in $5 \mathrm{ml}$ distilled water.

Deep blue color solution was obtained .which was changed into a green color. Then sublimed $\mathrm{I}_{2}$ was added and the method was continued as described above.

The product was characterized by infrared and ultraviolet spectra.

\subsection{Evolution of Antimicrobial activity:

Antimicrobial Susceptibilty
Testing:

Antimicrobial susceptibilty tests measure the ability of an antimicrobial agent to inhibit or to kill bacterial growth in vitro. This ability may be estimated by either the dilution method or the diffusion method.In this work the broth dilution method was followed.

Graded amount of antimicrobial substances are incorporated into liquid or solid bacterial media.The media are subsequently inoculated with test bacteria and incubated. The end point is taken as that amount of antimicrobial substance required to inhibit the growth of - or to kill- the test bacteria. 


\section{Procedure:}

A-Isolation :

Ceratin bacterial isolates were chosen, having in mind that they represent both $(\mathrm{G}+\mathrm{Ve})$ gram positive and $(\mathrm{G}-\mathrm{Ve})$ gram negative bacteria. The selected organisms were Escherichia coli. , Salmonella typhii and Paratyphoid, Shigella dysentery and Pseudomonas aeruginosarepresenting G- $\mathrm{Ve}$ while Staphylococcus aurous, clostridium welchii and Bacillus subtitles were representing the $\mathrm{G}+\mathrm{Ve}$. Those isolates were taken from patients at ( Central Public Health Laboratory) .

\section{B-Stock Chemical Solutions :}

Dissolved $0.75 \mathrm{gm}$ from the tested polymer in $10 \mathrm{ml}$ dilute solution ( containing $8 \mathrm{ml}$ distilled water and $2 \mathrm{ml}$ ethanol).

\section{Culture:}

1-Separate colonies from purified and identified isolated bacteria hours culture and incubated at $37 \mathrm{C}^{\circ}$ were selected and then cultured on both media ( brain heat infusion, or tryptic soy).

2-One $\mathrm{ml}$ of culture prepared of the selected isolates was added to $9 \mathrm{ml}$ of new fresh broth or normal saline.

3-Dilution of the polymer were done to used as antimicrobial and antifungal reagent at the concentrations of $0.066 \mathrm{gm} /$ $\mathrm{ml}, 0.049 / \mathrm{ml}, 0.033 \mathrm{gm} / \mathrm{ml}, 0.01 \mathrm{gm} /$ $\mathrm{ml}, 0.013 \mathrm{gm} / \mathrm{ml}, 0.005 \mathrm{gm} / \mathrm{ml}, 0.005 \mathrm{gm}$ $/ \mathrm{ml}$ of the polymer.

4- To each of the above prepared polymer tubes, $1 \mathrm{ml}$ broth of the prepared required organism was added .

5- The tubes incubated at $37 \mathrm{C}^{\circ}$ for 18 hours.

6- After 18 hour, sample was taken by a loop from the tubes and distributed uniformly on the agar media prepared in a petri-dishes $(90 \mathrm{~mm}$ diameter $)$. This was repeated for all concentration of the agent.
7- The dishes were kept for 18 hours incubation, then investigated visually to determine the inhibition of growth completely or partially.

The MIC is defined as the lowest concentration of antimicrobial agent at which there is no visible growth .Any hazy growth was ignored.

Moreover, one or two colonies on the spot with the agar method was also ignored.

N.B.A.blank experiment was carried out in the same manner using the dilute alone (ethanol ; distilled water). Without adding the antimicrobial agent.

\subsection{Evolution Of Antifungal Activity: \\ In this work the culture of the} organism method was followed.Dilution susceptibility test followed for antibacterial evalution was applied also for testing the activity of antifungal agents against .(Candida albicans ; yeast like candida and Alternaria).

MIC values were determines in the same manner for each agent examined however, the concentrations used with antifungicides were as follows . 0.066 $\mathrm{gm} / \mathrm{ml}, 0.049 \mathrm{gm} / \mathrm{ml}, 0.033 \mathrm{gm} / \mathrm{ml}$, $0.0166 \mathrm{gm} / \mathrm{ml}, 0.013 \mathrm{gm} / \mathrm{ml}, 0.005 \mathrm{gm} /$ $\mathrm{ml}, 0.005 \mathrm{gm} / \mathrm{ml}$ ).

\section{Results and Discussion:}

In tables $(1,2,3)$ are tabulated results obtained on using three prepared polymer derivatives as antimicrobial agents. According to the MIC values determined the polymers screened can be arranged in the following order.

$\mathrm{Cu} / \mathrm{I}_{2} / \mathrm{PVC}$ complex $>\mathrm{I}_{2} \mathrm{PVC}>$ Cyno Ethylated PVC.

The mechanism of action of most antimicrobial druges is not completely understood. However, the mechanism of action can be placed under five heading ( 8 $, 9,10)$.

1- Inhibition of cell wall syntheses. 
2-Inhibition of cell wall membrane function.

3-Inhibition of protein syntheses (i.e.) inhibition of translation and transcription of genetic material.

4- Inhibition of nucleic acid syntheses.

5-Competitive antagonism of same metabolite.

6- On complexing PVA with I 2 and metals the activity of the polymer against bacteria was profoundly increase and MIC was change from $0.066 \mathrm{gm} / \mathrm{ml}, 0.049 \mathrm{gm} / \mathrm{ml}$, $0.033 \mathrm{gm} / \mathrm{ml}, 0.0166 \mathrm{gm} / \mathrm{ml}, 0.013 \mathrm{gm} /$ $\mathrm{ml}, 0.006 \mathrm{gm} / \mathrm{ml}, 0.005 \mathrm{gm} / \mathrm{ml}$.

The possible made of action of metal containing compounds may be through removal of sulfhydryl groups (11). Enzyme protein containing cysteine have side chains termination in sulfhydryl groups.

Delivery of complexed iodine to the sensitive elements of the cell membrane to be the crucial events of antibacterial action $(11,12)$.Iodine targets are located in the bacterial cytoplasm and cytoplasmic membrane and its killing action takes place in a matter of seconds. In contact with polymer_bound iodine , sulfhydryl compounds, peptides, proteins , enzymes, vitamine $\mathrm{C}$, lipids and cytosine are iodinated and oxidaed by free iodine resulting in inactivation of molecules that are essential for biological viability $(11,12)$.

Many metals like wise interfere combining with sulfhydryl groups (13).

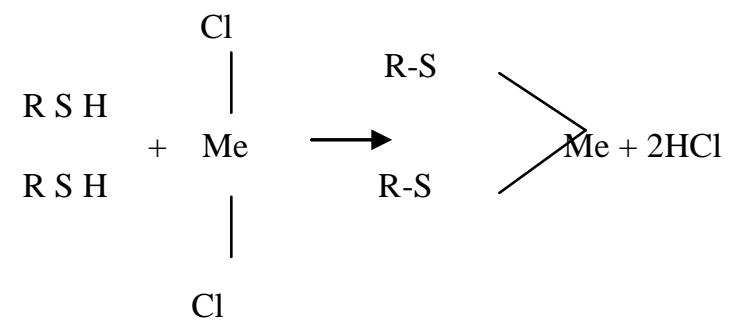

For this copper and iron are extremely toxic.

\section{Antifungal activity of the polymeric agent :}

The results of investigation of testing the polymer drugs prepared against three types of fungi are collected in table (4),(5) and (6).

The candida, yeast and alternia was found to be completely resistant to cyanoethylated PVA, irrespective of the fact that it was successful as antibacterial agent. However ,poly vinyl lcohol-iodine and polyvinyl alcohol-copper - iodine are shown to be microbacterial agents and act on a wide variety of bacteria (table 23).Polyvinyl alcohol, the hydrophilic polymer that acts as a carrier for iodine dose not have any intrinisic antimicrobial activity, but by virtue of its affinity to cell membranes, it delivers diatomic freeiodine $\left(\mathrm{I}_{2}\right)$ directly to the microbial cell surface .Similar results were found for polyvinylpyrrilidone iodine (14).

\section{Infrared Spectra:}

The spectrum of polyvinyl alcohol (fig.1)shows clear evidence of the presence of hydroxyl groups from the relatively intense band near $3500 \mathrm{~cm}^{-1}$ as polyvinyl alcohol is a secondary alcohol, the $\mathrm{C}-\mathrm{O}$ frequency of the $\mathrm{C}-\mathrm{OH}$ group occurs at $1400 \mathrm{~cm}^{-1}$ is also obtained Cyanoethylation lead to the introduction of nitrile group and appearance of nitrile absorption band at about $2200 \mathrm{~cm}^{-1}$ the region in which polyvinyl alcohol is relatively transparent (15).(fig 3) .In the spectra of $\mathrm{Cu}$ and $\mathrm{Cu} / \mathrm{I} 2$ complexes and adducts,(figs. 3-4) the absorption at 800$1020 \mathrm{~cm}^{-1}$, characteristic of complex and adduct structure, occurred (16). 


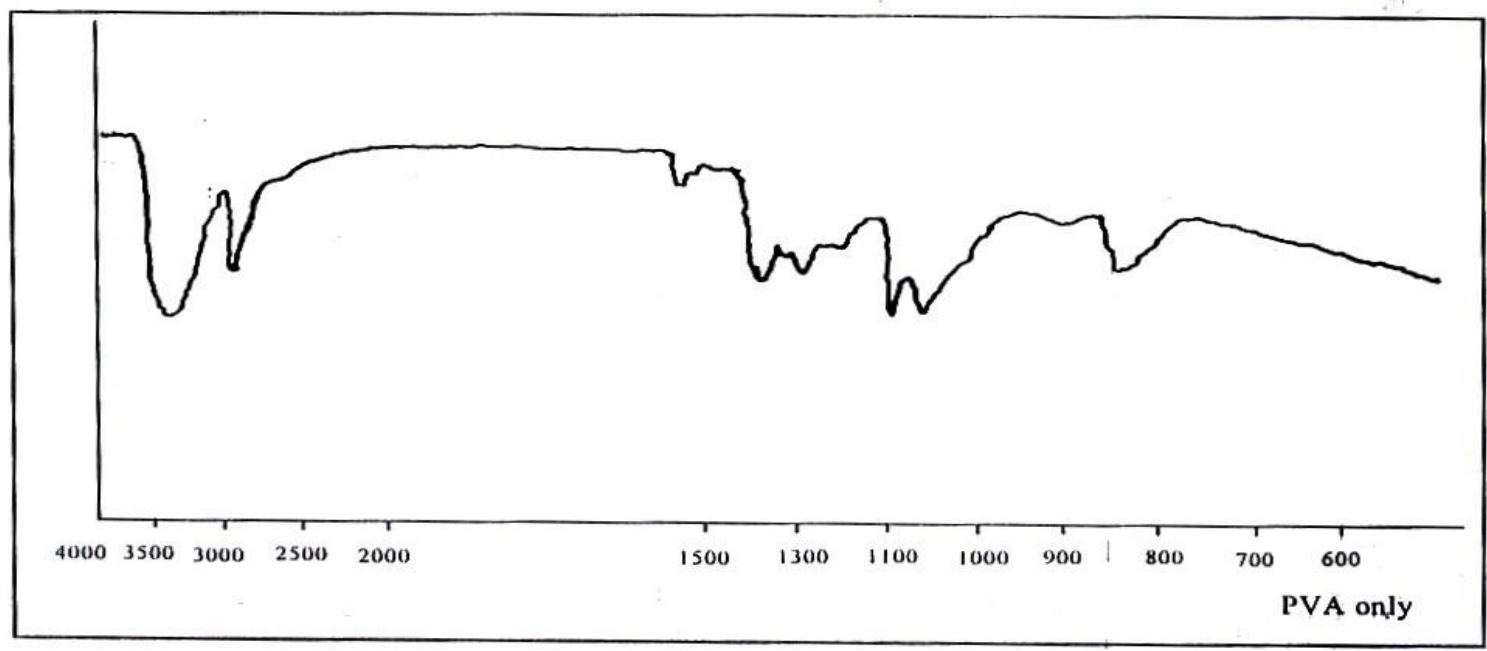

Figure (1):Infrared spectrum of Polyvinyl alcohol.

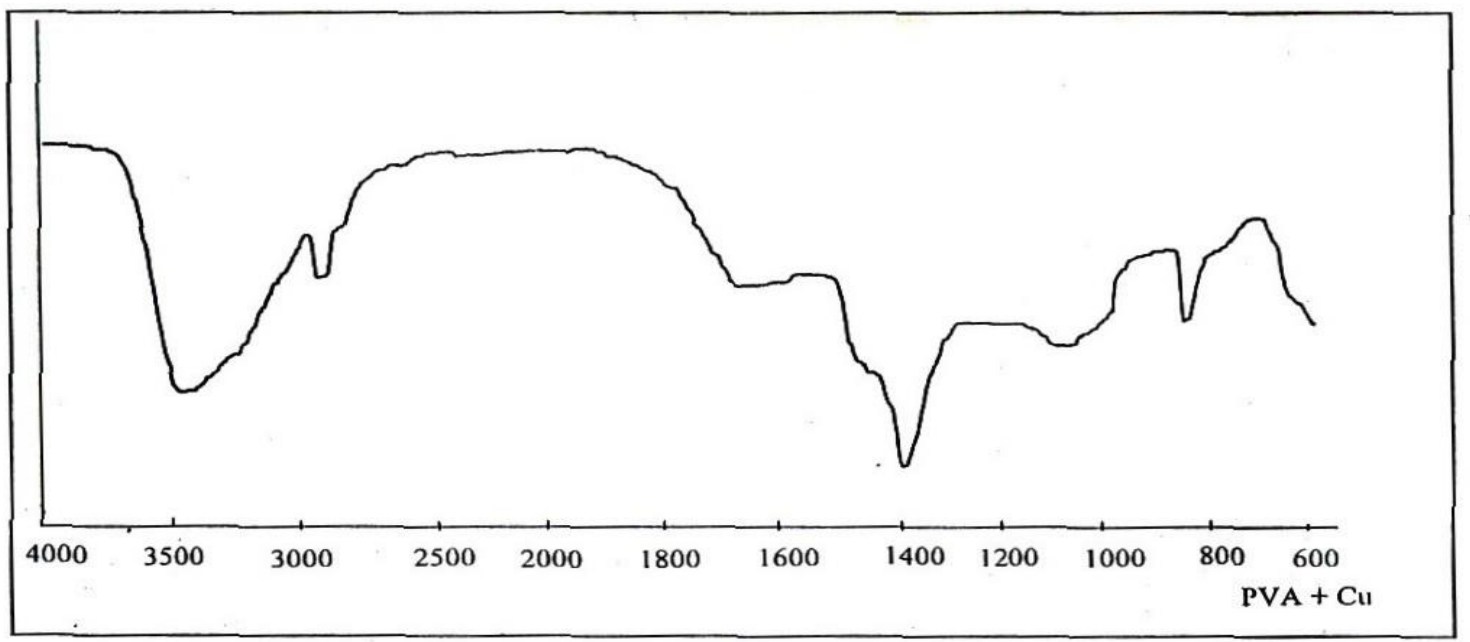

Figure (2):Infrared spectrum of Polyvinylalcohol $+\mathrm{Cu}$.

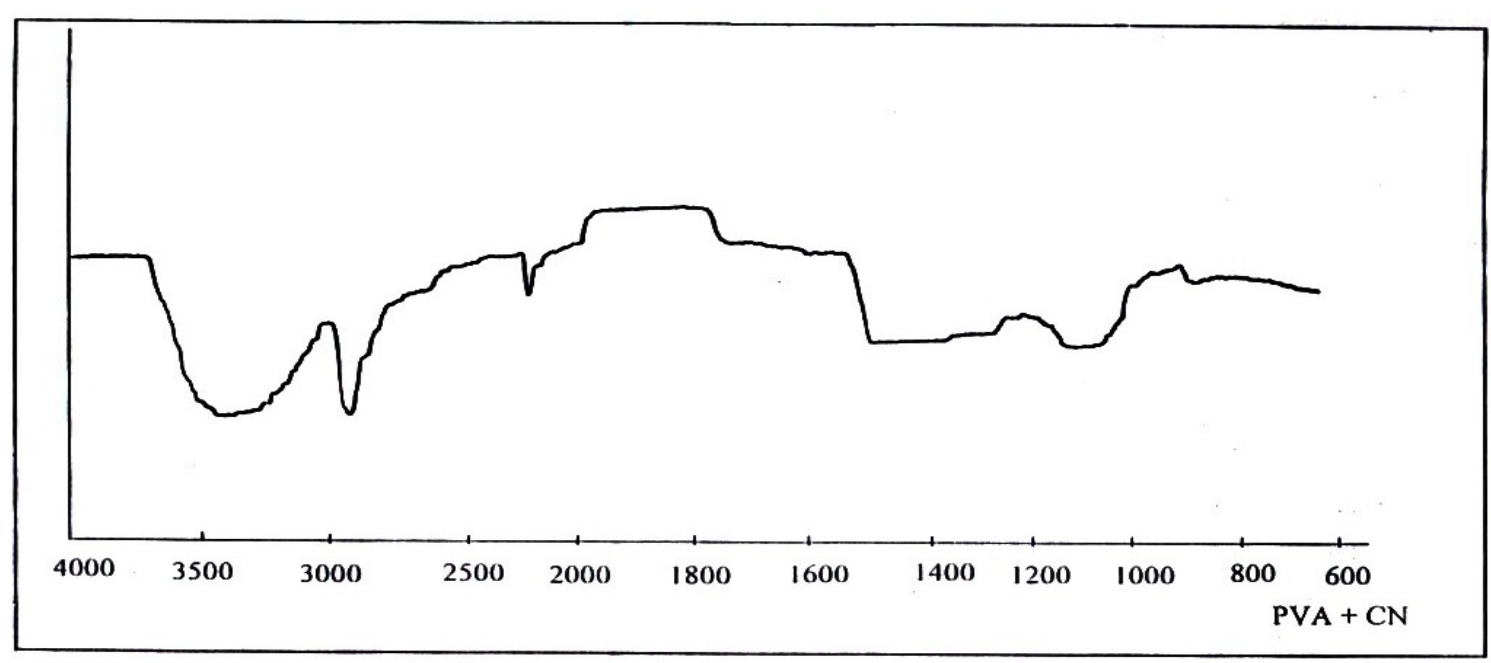

Figure (3):Infrared spectrum of Polyvinyl alcohol $+\mathrm{CN}$. 


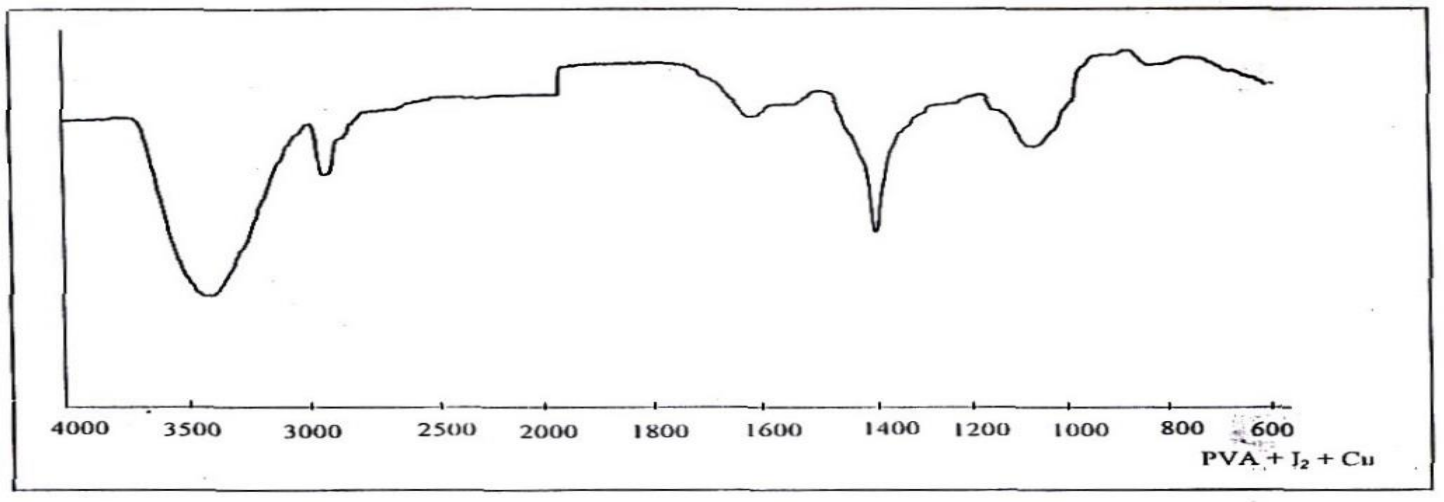

Figure (4): Infrared spectrum of Polyvinylalcohol $+\mathbf{I}_{2}+\mathrm{Cu}$.

\section{Ultraviolet Spectra:}

Fig. (5) show ultraviolet spectrum of poly (vinyl alcohol alone).It shows maximum absorption at $\lambda=202.3 \mathrm{~nm}$ and $\lambda=279.4 \mathrm{~nm}$.

On formation of complex with $\mathrm{Cu}$, salt, absorption is moved to the visible region at $612.1 \mathrm{~nm}$.fig.(6) show the $\mathrm{U}: \mathrm{V}$ Visible spectra for PVA $/ \mathrm{Cu} /$ Iodine compund :the absorption peak is now at $578.2 \mathrm{~nm}$.

This absorption band was show to be due to iodine complex or bound iodine and as can be seen from Fig.(7) it can present in the U.V.spectrum of only PVA plus iodine in alkaline media.

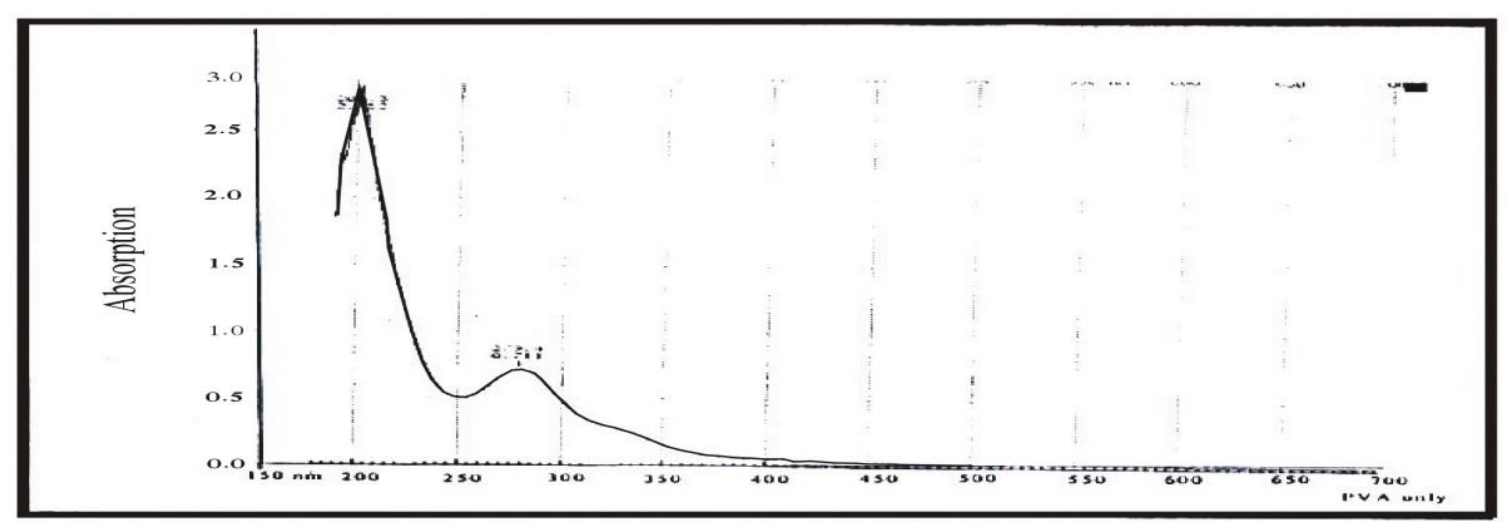

Figure (5):Ultraviolt spectrum of Poly vinyl alcohol .

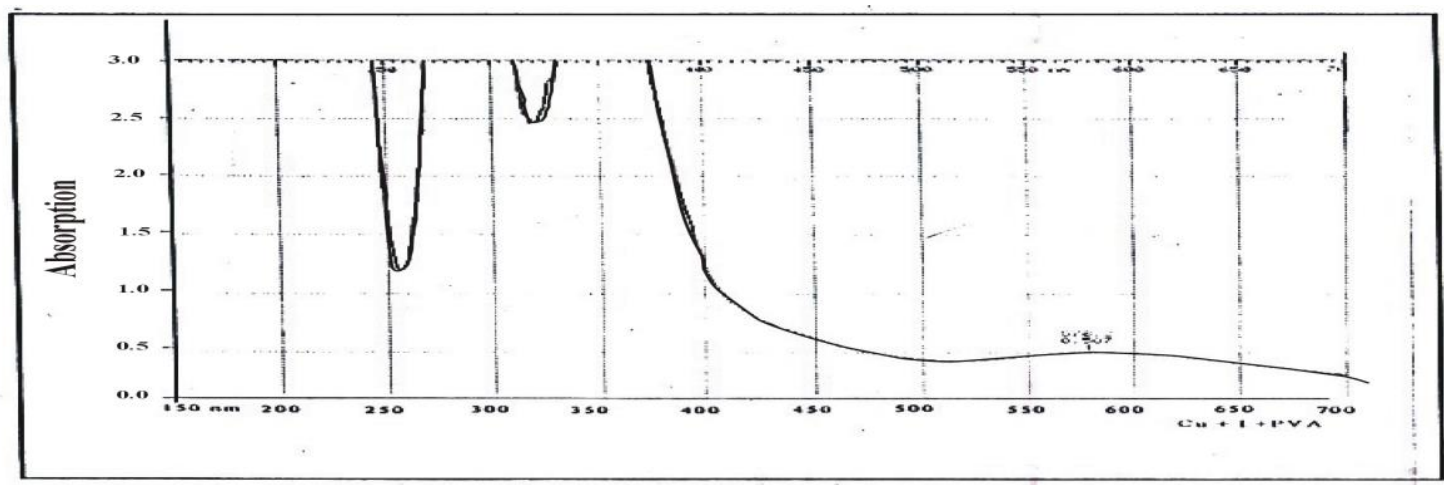

Figure (6): Ultraviolt spectrum of Polyvinyl alcohol $+\mathbf{I}_{2}+\mathbf{C u}$. 


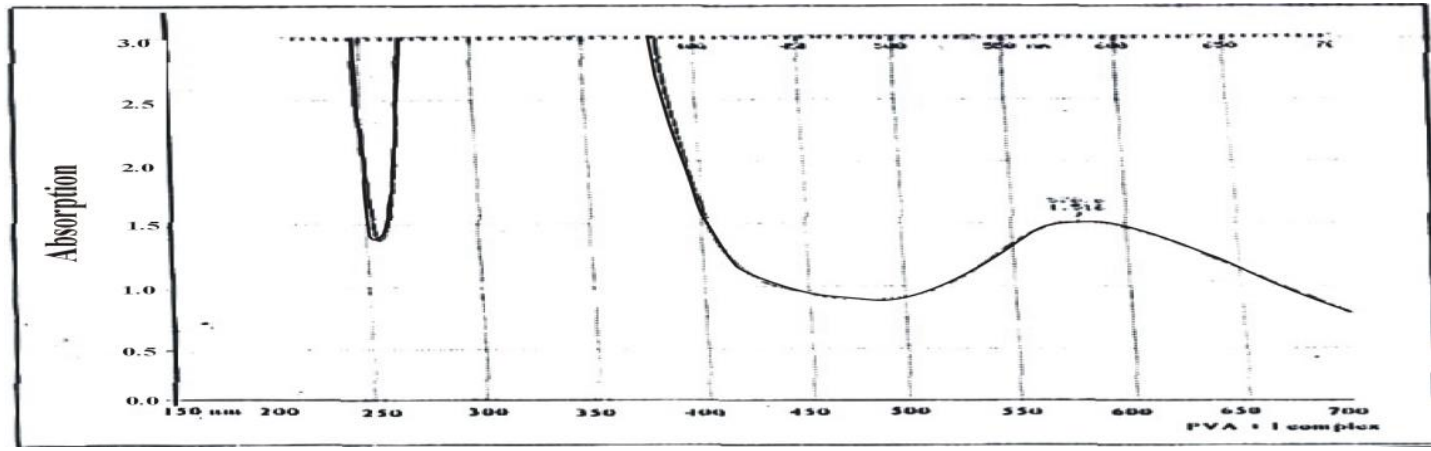

Figure (7):Ultraviolt spectrum of Poly vinyl alcohol $+\mathbf{I}_{2}$.

Table(1): Effect of Gyno Ethylated Poly Vinyl alcohol (CEPVA)on the Growth of Selected Bacterial Isolates.

$(-)$ no growth

\begin{tabular}{|c|c|c|c|c|c|c|}
\hline \multirow{2}{*}{ Isolates } & \multirow{2}{*}{$\begin{array}{c}\text { Gram } \\
\text { strain }\end{array}$} & \multicolumn{5}{|c|}{ Concentration of Antibacteria gm/ml. } \\
\cline { 3 - 7 } & & $\mathbf{0 . 0 6 6}$ & $\mathbf{0 . 0 4 9}$ & $\mathbf{0 . 0 3 3}$ & $\mathbf{0 . 0 1 6 6}$ & $\mathbf{0 . 0 1 3}$ \\
\hline Escherichia Coli & G-Ve & - & - & - & - & + \\
\hline Salmonella typhi Paratyphi & G-Ve & - & - & - & - & + \\
\hline Shegella dysentery & G-Ve & - & - & - & - & + \\
\hline Pseudomonas aeroginosa & G-Ve & - & - & - & - & + \\
\hline Klebsiella pneumoniae & G-Ve & - & - & - & - & + \\
\hline Neisseria gonorrhoea & G-Ve & - & - & - & - & + \\
\hline Staphylococcus aureus & G+Ve & - & - & - & - & + \\
\hline Bacillus subtilis & G+Ve & - & - & - & + & + \\
\hline
\end{tabular}

$(+)$ growth

Table(2): Effect of PolyVinyl alcohol / Iodine complex (PVA/ I) on the Growth of Selected Bacterial Isolates.

\begin{tabular}{|c|c|c|c|c|c|c|c|c|}
\hline Isolates & \multirow{2}{*}{$\begin{array}{c}\text { Gram } \\
\text { strain }\end{array}$} & \multicolumn{6}{|c|}{ Concentration of Antibacteria gm/ml. } \\
\cline { 3 - 9 } & G-Ve & $\mathbf{0 . 0 6 6}$ & $\mathbf{0 . 0 4 4}$ & $\mathbf{0 . 0 3 3}$ & $\mathbf{0 . 0 1 6 6}$ & $\mathbf{0 . 0 1 3}$ & $\mathbf{0 . 0 0 8}$ & $\mathbf{0 . 0 0 4}$ \\
\hline Escherichia Coli & Gre & - & - & - & - & - & + \\
\hline Salmonella typhi Paratyphi & G-Ve & - & - & - & - & - & - & + \\
\hline Shegella dysentery & G-Ve & - & - & - & - & - & - & + \\
\hline Pseudomonas aeroginosa & G-Ve & - & - & - & - & - & - & + \\
\hline Klebsiella pneumoniae & G-Ve & - & - & - & - & - & - & + \\
\hline Neisseria gonorrhoea & G-Ve & - & - & - & - & - & - & + \\
\hline Staphylococcus aureus & G+Ve & - & - & - & - & - & - & + \\
\hline Bacillus subtilis & G+Ve & - & - & - & - & - & - & + \\
\hline
\end{tabular}

(-) no growth

(+) growth

Table(3): Effect of PolyVinyl alcohol / Copper-Iodine complex (PVA/Cu- I) on the Growth of Selected Bacterial Isolates.

\begin{tabular}{|c|c|c|c|c|c|c|c|c|c|}
\hline \multirow{2}{*}{ Isolates } & \multirow{2}{*}{$\begin{array}{l}\text { Gram } \\
\text { strain }\end{array}$} & \multicolumn{8}{|c|}{ Concentration of Antibacteria gm/ml. } \\
\hline & & 0.066 & 0.049 & $\mathbf{0 . 0 3 3}$ & 0.0166 & 0.013 & 0.008 & 0.004 & 0.002 \\
\hline Escherichia Coli & G-Ve & - & - & - & - & - & - & - & + \\
\hline $\begin{array}{c}\text { Salmonella typhi } \\
\text { Paratyphi }\end{array}$ & G-Ve & - & - & - & - & - & - & - & + \\
\hline Shegella dysentery & G-Ve & - & - & - & - & - & - & - & + \\
\hline $\begin{array}{c}\text { Pseudomonas } \\
\text { aeroginosa }\end{array}$ & G-Ve & - & - & - & - & - & - & - & + \\
\hline $\begin{array}{c}\text { Klebsiella } \\
\text { pneumoniae }\end{array}$ & G-Ve & - & - & - & - & - & - & - & + \\
\hline $\begin{array}{c}\text { Neisseria } \\
\text { gonorrhoea }\end{array}$ & G-Ve & - & - & - & - & - & - & - & + \\
\hline $\begin{array}{c}\text { Staphylococcus } \\
\text { aureus }\end{array}$ & $\mathbf{G}+\mathbf{V e}$ & - & - & - & - & - & - & - & + \\
\hline Bacillus subtilis & $\mathrm{G}+\mathrm{Ve}$ & - & - & - & - & - & - & - & + \\
\hline
\end{tabular}

$(-)$ no growth

(+) growth 
Table(4): Effect of Cynothylated PVA (CEPVA) on the Growth of Selected fungal Isolates.

\begin{tabular}{|c|c|c|c|c|c|}
\hline \multirow{2}{*}{ Isolates } & \multicolumn{6}{|c|}{ Concentration of Antifungal gm/ml. } \\
\cline { 2 - 6 } & $\mathbf{0 . 0 6 6}$ & $\mathbf{0 . 0 4 9}$ & $\mathbf{0 . 0 3 3}$ & $\mathbf{0 . 0 1 6 6}$ & $\mathbf{0 . 0 1 3}$ \\
\hline Candida albicans & + & + & + & + & + \\
\hline Yeast like fungal & + & + & + & + & + \\
\hline Alternaria & + & + & + & + & + \\
\hline
\end{tabular}

(+)growth

Table(5): Effect of polyvinal alcohol /Iodine complex (PVA/I) on the Growth of Selected fungal Isolates.

\begin{tabular}{|c|c|c|c|c|c|c|}
\hline \multirow{2}{*}{ Isolates } & \multicolumn{6}{|c|}{ Concentration of Antifungal gm/ml. } \\
\cline { 2 - 7 } & $\mathbf{0 . 0 6 6}$ & $\mathbf{0 . 0 4 9}$ & $\mathbf{0 . 0 3 3}$ & $\mathbf{0 . 0 1 6 6}$ & $\mathbf{0 . 0 1 3}$ & $\mathbf{0 . 0 0 8}$ \\
\hline $\begin{array}{c}\text { Candida } \\
\text { albicans }\end{array}$ & - & - & - & - & - & + \\
\hline $\begin{array}{c}\text { Yeast like } \\
\text { fungal }\end{array}$ & - & - & - & - & - & + \\
\hline Alternaria & - & - & - & - & - & + \\
\hline
\end{tabular}

(-)no growth

(+)growth

Table(6): Effect of polyvinal alcohol / Copper-Iodine complex (PVA/Cu-I) on the Growth of Selected fungal Isolates.

\begin{tabular}{|c|c|c|c|c|c|c|c|}
\hline \multirow{2}{*}{ Isolate } & \multicolumn{7}{|c|}{ Concentration of Antifungal gm/ml } \\
\cline { 2 - 9 } & $\mathbf{0 . 0 6 6}$ & $\mathbf{0 . 0 4 9}$ & $\mathbf{0 . 0 3 3}$ & $\mathbf{0 . 0 1 6 6}$ & $\mathbf{0 . 0 1 3}$ & $\mathbf{0 . 0 0 8}$ & $\mathbf{0 . 0 0 5}$ \\
\hline $\begin{array}{c}\text { Candidaicans } \\
\text { albicans }\end{array}$ & - & - & - & - & - & - & + \\
\hline $\begin{array}{c}\text { Yeast like } \\
\text { fungal }\end{array}$ & - & - & - & - & - & - & + \\
\hline Alternaria & - & - & - & - & - & - & + \\
\hline
\end{tabular}

(-) no growth

(+) growth

\section{References:}

1- Hinriches, W.L.J. ; Brock , S.N. ; Van de Wetering P.and Hemink, W.E. (1999) Preparation of some polymers for pharmacological purposes. J.of Controlled Release 60:249

2-Ikada ， T.; Tazuke S.;and Suzki Y..Makrrol. (1984) Identification of some polymers as a anti miceobial .Makrrol.Chem., 185 : 869

3- Senuma,M.;Tashiro T.;Iwakura M.and Kaeriyama K. (1989) Use of some polymers as a antibacterial magents. J.Appl.Polym.Sci,37: 2837.
4- Betz , H.G. (1980) In Advances in polymer Science, Springer Verlag, Berlin.

5- Hay, J.Mand Lyon , D. (1967) Nature. .pp.216. INC. company.

6-Vino product Handbook1980.Air Product and Chemical, Inc.,Allentown,Pa., 7-Toshihiro, M.; Akira O; and Sadao H. (1986) Preparation of PVA compounda and creation some complexes. J.Appl. Polym. Sci ,32 : 3919

8-Fauci , S.; Broun warld E.Lsselbacher D.Wilson D.; Martin B. ;Kasper L.; Hauser L. AND Long.L. Hanison,s. .(1998) Principles of Internal Medicine , Fourth Edition Volum 1, Mc-Grow Hill, America.

9- Cary, C.D.(1998) Pharmacology .3r.edn . Willams one willkens .

10-Groth , A. and Resell , E.S. (1984) Medical Pharmocology $11^{\text {th }}$ .ed.C.V.Mosby Company, S.T.ious

11- Jawetze ， E. ; Melnick ， J.L .and Adelberg E. A. (1980) Review of Medical Microbiology Lang Medical Publication, Los Altos California.

12-Zamora , J.L . Price M.E. ; Chuang P., (1985) Identification of cell sides specilized to connect compound complexes. Lurgery 98(1): 25.

13-Zamora ,J.L. (1986) Chemical Abstract J.L. The Am.J.of Lurgery, 15 $\mathrm{HOO}$

14-Zanera ,V.L. (1986) Chemical abstract.P.The Am.J.of Leergery ,151: 400.

15- Haslam , J; Willis .H.A. and Squirrel .D.C.M. (1972) Identification and Analysis of Plastics .Iilife Books, $2^{\text {nd }}$ edn, London

16-Mokhnach ，V. O.; Zueva .I.P.and Zh.Neorgan .Khim . (1963) Characteristics of some elements complexes. through Chem Abstr.;58,13304 h . 
تحضير و تقييم مشتقات البولي فنيل الكحول كمضادات للبكتريا و الفطريات

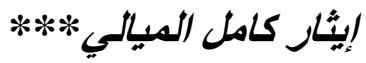

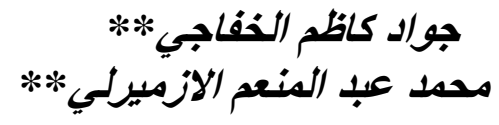

* تلي نوري عبل

*قسم العلوم ، كلبة التربية الأساسية ، الجامعة المستتصرية.

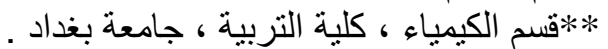

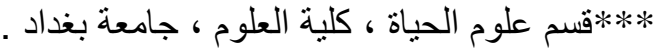

تم تحضير مشتنقات البولي فنيل الكحول السيانو اثثلينية كذاكلك معقداته مع النحاس الثنائي ، ومعقداته مع النحاس

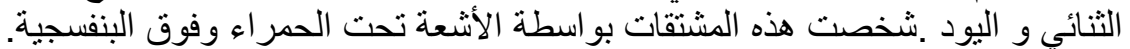

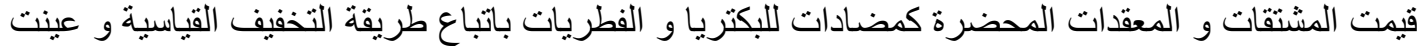

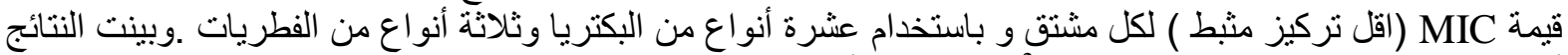

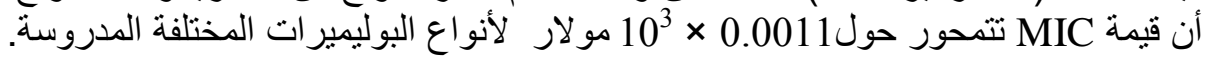

